Western University

Scholarship@Western

Political Economy Research Group. Papers in

Political Economy

Economics Working Papers Archive

1994

\title{
On the Nature of Nationalism: An Appraisal of Ernest Gellner's Writings on Nationalism
}

Brendan O'Leary

Follow this and additional works at: https://ir.lib.uwo.ca/economicsperg_ppe

Part of the Economics Commons

Citation of this paper:

O'Leary, Brendan. "On the Nature of Nationalism: An Appraisal of Ernest Gellner's Writings on Nationalism." Political Economy Research Group. Papers in Political Economy, 47. London, ON: Department of Economics, University of Western Ontario (1994). 
POLITICAL ECONOMY RESEARCH

GR () UP

\title{
PAPERS IN POLITICAL ECONOMY
}

\author{
Paper No. 47
}

"On the Nature of Nationalism: An Appraisal of Ernest Gellner's Writings on Nationalism"

Brendan O'Leary

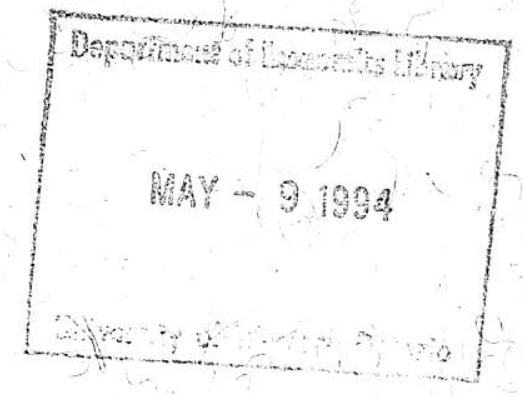

The UNIVERSITY of WESTERN ONTARIO 
The Political Economy Research Group was established in the faculty of Social Science at the University of Western Ontario in 1988. Its purpose is to foster scholarship, teaching and interdisciplinary research in political economy, with a focus on:

1. the application of economic models and methods to the study of political processes and institutions,

2. the economic impact of political processes and institutions,

3. the influence of economic factors on the formation of public policy. and on institutional change,

4. the politics of economic policy making,

5. the political, social, and economic effects of public policy.

\section{Co-directors:}

Ronald Wintrobe (Economics)

Robert Young (Political Science)

Board of Directors:

Peter Howitt (Economics) .

B.B. Kymlicka (Pólitical Science)

John N. McDougall (Political Science)

Peter Neary (History)

John Whalley (Economics)

Staff:

Jayne Dewar

For further information:

Political Economy Research Group,

Department of Economics,

Social Science Centre,

London, Ontario, Canada N6A 5C2

phone: (519) 661-3877

fax: (519) 661-3292 


\title{
On the Nature of Nationalism

\author{
An Appraisal of Ernest Gellner's Writings on Nationalism
}

\author{
(c) Brendan O'Leary \\ Reader in Political Science and Public Administration \\ London School of Economics and Political Science \\ [second draft ${ }^{1}$ ]
}

\begin{abstract}
'The theoretical problem is to separate the quite spurious 'national' and 'natural' justifications and explanations of nationalism, from the genuine, time- and context-bound roots of it.'
\end{abstract}

Ernest Gellner, Thought and Change (1964: 151).

Nationalism is the most potent principle of political legitimacy in the modern world. It is the doctrine that the nation should be collectively and freely institutionally expressed, and that it should be ruled by co-nationals. The appeal of Ernest Gellner's writings is that they claim to explain why nationalism has become the key principle of political legitimacy, and for this reason alone they deserve scrutiny by all political scientists. Gellner's writings on nationalism are now receiving renewed attention, especially throughout Europe - where exhilarating and tragic events east and south of the Elbe, and little local difficulties in the west, like the passage of the Maastricht Treaty, have demonstrated that nationalism retains the capacity to shake states and empires, as well as the pieties of devout conservatives and cosmopolitan liberals and socialists ${ }^{2}$.

In numerous essays and two books this fluent, prolific and witty philosopher, anthropologist, sociologist and multi-lingual polymath provides lucid and persuasive accounts of why nationalism is a necessary component of modernity ${ }^{3}$. These accounts disturb both conservatives and secular rationalists. The reasons are not hard to seek. Nationalism relegates religion to a secondary, and even inessential, principle of a stable and legitimate political order. It thus challenges traditionalist conservatism. Nationalism, at least as it is normally interpreted, also suggests that law, reason, utility, material prosperity and social justice are secondary principles in establishing a stable and legitimate political order. Nationalism's exponents and its ideas have therefore provoked persistent condemnation from secular liberals and socialists for some two hundred years 4 .

Gellner's explanation of nationalism does not appease pious conservatives in the least. Indeed his writings on nationalism are best interpreted as a sustained criticism of a very pious Oakeshottian conservative, the late Elie Kedourie, Gellner's former colleague at the LSE. However, Gellner's explanation of nationalism is intended to be partially reassuring for secular liberals, and one of the questions I wish to address is whether he provides the right kind of reassurances. 
This essay focuses on scrutinising the core arguments of Gellner's Thought and Change (1964) and Nations and Nationalism (1983). I will only refer to Gellner's other writings on the subject in parenthesis. This textual focus is justified because Nations and Nationalism is Gellner's most elaborate statement on the subject; and because it is largely an expansion of the themes first sketched in Thought and Change; and lastly because he has not, to my knowledge, repudiated any of the core propositions advanced in these texts.

\section{Thought and Change.}

Gellner's first extensive statement on nationalism, published in 1964, begins from the recognition that both Liberalism and Marxism got nationalism wrong. They assumed it was doomed, a legacy of outmoded irrationalism, superstition and savagery, or a necessary but temporary stage in the path to global utilitarianism or global socialism. They were both, to put matters mildly, a touch previous in their assumptions. Indeed while Marxism is now fast heading towards its grave nationalism remains in vigorous and rude health. Nevertheless, despite the errors of Liberalism and Marxism Gellner was concerned to establish that the reasons they were wrong were not because two other popular theories are right, namely 'Dark Gods theory' and 'naturality theory'.

'Dark Gods theory' has it that nationalism is the inevitable expression of the atavistic, irrationalist passions which motivate human beings - in short it is a version of original sin theory 5 . Gellner rejects this idea as 'utter nonsense' - even when it includes some sensible premises like the importance of belonging, identification, and exclusion in human behaviour ${ }^{6}$. The fact that human beings have always been organised in groups with loyalty-instilling capacities must be distinguished from their more recent and historically novel propensity to identify with the modem anonymous nation.

'Naturality theory' has it that people have nationalities in the way that they have eye-brows and blood-groups, and that it is natural that those who share a nationality should wish to share the same political unit, and that that is a good thing. Gellner, by contrast, insists on the contingency of nationalism. However, he suggests that it is underpinned by social foundations:

there are undoubtedly overwhelmingly powerful factors in the contemporary and recent social conditions which do make these [nationalist] suppositions ... natural and probably irresistible. ${ }^{7}$ 
This contention is both a rejection of nationalists' 'naturality' theory and a rejection of Elie Kedourie's argument that nationalism is the result of a world-historical intellectual error: an accidental and bad set of ideas, loosely derived from Kant, and disseminated by philosophical incompetents who have sown disastrous consequences.

Against the 'naturality' theory Gellner points out that the typical political units for most of human history were not animated by nationalist principles: nationalism did not feature in small tribal or village units, city states, feudal entities, dynastic empires, or in the loose moral communities of a shared religion. These political units rarely, and only accidentally, coincided with those of 'nations', 'i.e. linguistic and cultural boundaries'8. In pre-modern times the nationality of the governors was not a fundamental issue of legitimacy for the governed. Then they simply asked of their rulers whether they were 'less corrupt and grasping, or more just and merciful' than their predecessors?.

Now, to employ the concepts of social anthropology, the relationships between 'structure' and 'culture' have changed. Now nationalism does matter as a principle of political legitimacy, precisely because culture has become so important that it 'does not so much underline structure: rather, it replaces it' ${ }^{10}$. In pre-modern societies social 'structure', i.e. the system of social roles, is tightly circumscribed, nested and ascriptive, and for this reason shared linguistic and cultural communication is not essential to the preservation of social order and effective interaction. By contrast, in modern times in which social roles become open and changeable, 'those who communicate must speak the same language, in some sense or other', and the classification of people by 'culture' is of course classification by 'nationality'. ${ }^{11}$

The negative social foundations of nationalism are thus explained by the erosion of rigid social structures which make a shared culture much more important in creating and sustaining social cohesion. The positive social foundations of nationalism, in contrast, are explained by economies of scale in the production of literate citizens by state-sponsored educational systems. The minimal political unit, which used to be circumscribed by defence or economic requirements, 'is now determined by the preconditions of education' ${ }^{12}$, which means a political unit larger than that of the family, village and city-state. Moreover, the relevant educational system must operate 'in some medium, some language (both in the literal and the extended sense) ${ }^{\prime 13}$. The argument is that universal literacy is now an essential aspect of a normally socialised human being, and that that condition is generated by state-sponsored educational systems, which are multiply facilitated if the idioms of the home and the school become the same. In turn modern educational systems explain the cultural identifications which can move so many human beings. However, these identifications with the nation have historically recent and novel foundations: modern people 
do not in general become nationalists from sentiment or sentimentality, atavistic or not, wellbased or myth-founded: they become nationalists through genuine, objective, practical necessity, however obscurely recognised ${ }^{14}$.

Gellner thus provides a schematic account of why modern loyalty-invoking units are not very small (local, like tribal, feudal or classical units), because functioning educational systems have to operate on a broader scale; and of why they are cultural units, because a shared culture is an indispensable feature of a modern social system. He then goes one stage further, by trying to explain why these cultural units tend to be smaller than those of agrarian religious civilisations (e.g. Christendom or Islam), even though these wider civilisations could have furnished a shared language or culture; or, to put matters in another way, he seeks to explain the divisiveness of nationalism, and why it fractures wider political entities, like the empires of the ancien regime.

His answer, briefly, is that 'nationalism is a phenomenon connected not so much with industrialisation or modernisation as such, but with its uneven diffusion'. ${ }^{15}$ The uneven impact of the successive waves of industrialisation and modernisation generate sharp stratifications between peoples which are not hallowed by custom, which are not easily politically regulated, but which are feasibly remediable by the option of 'national' secession. Intelligentsias who experience blocked social mobility, and who share cultural traits with proletarians experiencing multiple humiliations in urban environments and discrimination in labour markets, provide the personnel for nationalist movements. These intelligentsias and proletarians seek to establish their own nation-states if they presently have no feasible prospect of being fairly treated or assimilated - which Gellner seems to treat as the same thing. These nation-states will be modern states, or at least they will be structured as such, even if in ideological self-deception the nationalist intelligentsia romantically believe themselves to be restoring their old nation. They will talk like narodniks but act as westernisers ${ }^{16}$. Contrary to the received wisdom of nationalist historiographers, poets and philologists

Nationalism is not the awakening of nations to self-consciousness: it invents nations where they do not exist - but it does need some pre-existing differentiating marks to work on, even if ... these are purely negative. ${ }^{17}$

These are the core propositions, admittedly schematised, of the theory of nationalism adumbrated in Thought and Change.

Gellner anticipated criticisms by clarifying and qualifying his theses in several ways: 
(a) He recognised that 'some pre-modern loyalty-evoking political units', notably the strong dynastic states of the Atlantic seaboard of Europe, embraced populations and covered territories 'similar to those which one would expect to be produced by modern nationalism', and posed the question 'do these rather different phenomena, so close to 'nationalism', contradict the theory?'18 In reply, he seems to have suggested, in a dense and slightly confusing passage, three possible theory-saving options:

(i) to accept that the modernising forces which generate nationalism had been operating in Europe at least since the Reformation, or

(ii) to refuse to classify these phenomena with modern nationalism (which seems to leave open the possibility of a non-modern nationalism ?), or

(iii) to suggest that a pre-modern shared culture, including membership of a dynastic state whose boundaries roughly overlapped with a language, might be $a$ factor, amongst others, in inclining people in the direction of particular political bedfellows for the construction of a modern nation.

Gellner's ambition is to protect his theory from the charges that it is tautological and/or unfalsifiable. The purpose is clear. He wishes to separate the modern phenomena - 'citizenship through education, group differentiae in terms of the language of instruction, and unmediated membership of mass co-cultural societies' - from other superficially related phenomena 'even if a few of those others also make a banner of language-and-culture'. ${ }^{19}$ The latter, we may take it, are the religious and linguistic imperialisms of some ethnically based pre-modern dynasties.

(b) Gellner insists that 'it is impossible to predict with confidence, prior to the crystallisation of this or that nationalism, just which 'nations' will emerge'. ${ }^{20}$ His argument is this: cultural differences are widespread and real, and injustices, exploitation, humiliation are equally so, but $t$ isn't easy to tell which identifications and oppositions will emerge to produce specific nationalisms. He recognises that this predictive weakness may make his theory look suspiciously untestable, but we are left with the impression that it can be tested in other ways, and that it has the merit of rejecting two possible alternative theories:

(i) the thesis that all pre-modern cultures will inevitably generate nations, and

(ii) the thesis that some pre-modern cultures are far more likely than others to form the raw materials of modern nations.

(c) Gellner also recognises that nationalism is not an all-powerful or all-pervasive political force. There are, first of all, exceptional zones which have resisted the norm of one culture, one polity. He mentions Switzerland, Belgium and Canada. The last two cases do not concern him too 
much because he considers the weaknesses of Belgian and Canadian nationalism confirm the theory's implicit assumption that bilingual or multilingual states will be less nationally stable than those which are monolingual. Switzerland is more embarrassing: Gellner describes it as 'a traditional society which has weathered modernisation' so it can tolerate linguistic pluralism. He also maintains that there 'is a sense in which various kinds of Swiss 'speak the same language' even if they do not do so in a literal sense'. ${ }^{21}$ A curious argument.

Secondly, Gellner briefly recognises that just as nationalisms can be obstructed or modified 'by special circumstances', so they can also be facilitated by power-politics which may manipulate nationalist ideas, or by the dissemination of political norms which are infused with nationalist assumptions. He mentions what for him is an homely example, the formation of the Czech national state which resulted from a coalition between Czech intellectuals and western foreign policy.

(d) Finally, Gellner closes his first discussion of his explanatory theory by briefly evaluating nationalism. He does not waste any time condemning nationalist chauvinism in the standard manner of liberal cosmopolitans. He considers that the 'main boon which nationalism has conferred on mankind ... may well be political'. These political benefits are not merely confined, however, to the psychological blessings nationalism confers - the dignity and self-respect arising from the elimination of 'second- or $n$th class citizenship' and the benefits liberated peoples enjoy from not being 'bossed and knocked about by others with whom they cannot or are not allowed to identify', and being bossed and knocked about by 'their own' people instead 22 .

The major political benefit that nationalism has confirmed on humanity is much more extensive: it has preserved pluralism in the world political order, and thereby preserved political liberalism in parts of the world. Gellner reaches this conclusion by considering the most feasible counterfactual antonyms of a world of nation-states: a world-government or a world in which the major empires of the late nineteenth century had been preserved. In either of these counterfactual worlds he believes that liberalism would have gone by the board. A world government passing through the second, global phase of industrialisation, he suggests, would have resembled South Africa under apartheid, i.e. a coercively organised hierarchy of races and ethnic communities; while a world of industrialising empires would have been wracked by ferocious battles over citizenship fought between the metropolitan cores of the empires and the more numerous and poorer peoples of the territories they had conquered. The ironic message is not spelled out, but it is clearly there for all to read: nationalism, unintendedly, preserved the miracle of western liberalism precisely because it inhibited global despotism, and because it helped destroy the world of the European empires. For this reason, if no others, liberals should take comfort from the benign repercussions of nationalism. 


\section{Nations and Nationalism.}

Gellner's theory of nationalism, as articulated in Thought and Change, as far as I have been able to discover, went largely unnoticed in the writings of political scientists, political sociologists and political philosophers- perhaps because it is buried within a wider discussion of philosophy and social change, and perhaps because it was patronisingly classed as a provincial 'English' variation on the themes of the modernisation school then ascendant within American social science. ${ }^{23}$. Thought and Change was known to political scientists, if at all, for sharply stating the conventional wisdom of the emergent affluent society of the late 1950s and the early 1960s: a modern state has one key principle of political legitimacy, the GNP must increase. The other key principle, that the state must be a nation-state, was less remarked upon.

In complete contrast Gellner's book-length statement of his theory, wittily expounded nearly two decades later in Nations and Nationalism (1983), was very well received amongst political scientists and political sociologists who study nationalism, and those who do not, and rightly so 24 . Nations and Nationalism is at once more sociologically ambitious than Thought and Change, bearing the imprint of Gellner's dialogues with Durkheim and Marx; more conceptually novel, displaying his desire to get the value-added of his theory across to other scholars; and it is more empirically promising, as it sets out a typology of nationalism-inducing and nationalism-thwarting situations, presumably meant to be of benefit to those engaged in comparing different types of nationalism.

There are, of course, fundamental continuities between Thought and Change and Nations and Nationalism, but there are also important elaborations on the original theses. First, Gellner now rejects four erroneous theories of nationalism:

- the nationalist theory that it is natural, self-evident and self-generating;

- Kedourie's theory that it is a contingent and artificial consequence of 'ideas which did not need ever to be formulated, and appeared by a regrettable accident', and is inessential to the life of industrial societies25;

- Marxism's 'Wrong Address Theory' which suggests that the liberationist message intended for classes was 'by some terrible postal error' delivered instead to nations - an error which can be corrected by appropriately corrective revolutionary conduct, and

- 'Dark Gods Theory'26.

Secondly, he maintains the thesis that nationalism is an essential component of modernisation, of the transition from agrarian to industrial society - the latter requiring a state which can produce and 
be maintained by one common, literate and accessible culture. However, the vocabulary in which this idea is expressed has changed because it is now part of a wider philosophy of history. Nationalism is now defined as

the general imposition of a high culture on society, where previously low cultures had taken up the lives of the majority, and in some cases the totality, of the population. It means the general diffusion of a school-mediated, academy-supervised idiom, codified for the requirements of a reasonably precise bureaucratic and technological communication. It is the establishment of an anonymous impersonal society, with mutually substitutable atomised individuals, held together above all by a shared culture of this kind, in place of the previous complex structure of local groups, sustained by folk cultures reproduced locally and idiosyncratically by the micro-groups themselves (my italics). ${ }^{27}$

The preconditions and maintenance of nationalism still include widespread or universal literacy, a society committed to economic growth through its formal commitment to social mobility - both horizontal and vertical. This industrial society requires effective and widespread context-free communication through a common cultural medium, a 'high culture'. Communicative media are placed centre-stage in generating and maintaining nationalism, but in an argument which stresses the functionality of a shared culture for the effective operation of modern work-organisations and bureaucracies. 28

Thirdly, nationalism is still seen as distinctive to a particular phase in human history, but this argument is now part of an elaborate 'philosophy of history', which distinguishes three phases in human progress: the pre-agrarian, the agrarian and the industrial. This philosophy is a considerably re-worked, but non-teleological form of historical materialism ${ }^{29}$. Each of the three key phases in human history is associated with characteristic modes of production, coercion, culture and cognition. Nationalism is a cultural phenomenon distinctive to industrial society, and is intimately connected to the mode of production characteristic of that society. Nationalism would have made no sense in tribal societies because such societies were and are stateless, and therefore the ambition of nationalism, to unify the national culture and the state, is incoherent in such circumstances. In the 'agro-literate' polity, the imperial structure characteristic of the most developed forms of agrarian society, nationalism also would have made no sense, because such empires had no reason to require their elites and peasant masses to share a common culture. In the industrial society nationalism is an essential part of the cultural atmosphere of such societies - its 'exo-socialisation', i.e. schooling, training and educating persons in a culture which mostly frees them from familial and corporate ties is a sine qua non of social cohesion. To these suppositions Gellner adds a modified Durkheimian account of religion and normative orientations through the ages, which is buckled on to his philosophy of history. Whereas tribal societies worship themselves indirectly (in the form of spirits); agrarian societies worship their rulers directly or indirectly (in the form of 
monotheistic religions); while in industrial societies the participants worship themselves (nationalism). Nationalism, it seems, is the functional equivalent for industrial societies of the world-religions of agro-literate polities, and of the animistic cults of pre-agrarian bands, nomads and tribes.

Fourthly, Gellner now provides a typology of 'nationalism-inducing and nationalism-thwarting situations' which considerably amplifies the crude 'model' of what induces nationalism sketched in Thought and Change $e^{30}$. There are three dimensions to the typology. Gellner differentiates:

(i) power-holders from the rest: $P$ and -P;

(ii) those who have had access to a modern education or a viable modern high culture from those who have not: $\mathrm{E}$ and $-\mathrm{E}$; and

(iii) a polity in which the power-holders and the rest, and the educated or uneducated, share a homogeneous culture ( $A$ and $A$ ), from one in which they do not ( $A$ and $B$ ).

These three dimensions generate the eight possibilities in Figure 1. A line containing $A$ and $A$ represents a culturally homogeneous territory, whereas a line containing A and B represents a bicultural territory.

$\begin{array}{llll} & \mathbf{P} & -\mathbf{P} & \\ & - \text { E } & \text {-E } & \\ 1 & \text { A } & \text { B } & \text { typical pre-nationalist situation } \\ 2 & \text { A } & \text { A } & \text { untypical pre-nationalist situation } \\ & \text { E } & - \text { E } & \\ 3 & \text { A } & \text { A } & \text { early industrialism without ethnic catalyst } \\ 4 & \text { A } & \text { B } & \text { ethnic nationalism } \\ & \text { E } & \text { E } & \\ \text { 5 } & \text { A } & \text { A } & \text { mature homogeneous industrialism (established nationalism). } \\ \text { 6 } & \text { A } & \text { B } & \text { classical liberal Western nationalism } \\ & \text {-E } & \text { E } & \\ 7 & \text { A } & \text { B } & \text { diaspora or 'middle-man' nationalism } \\ 8 & \text { A } & \text { A } & \text { Decembrist revolutionary, but not nationalist, situation }\end{array}$

Figure 1. Gellner's Typology of Nationalism-Inducing and Nationalism-Thwarting Situations Source: adapted from Emest Gellner, Nations and Nationalism, 94. [Nationalism-generating situations in italics]

The typology is intended to suggest four situations in which nationalism will be engendered, and four in which it will be absent or thwarted. Consider the latter first. In two cases, lines 1 and 2, 
where no one, power-holder or non-power-holder has access to modern education, nationalism cannot exist, ex hypothesi. The typical agro-literate polity, line 1, is not culturally homogeneous, although a few such specimens might exist, line $2^{31}$. In the third scenario, line 8 , the old ruling class of the agro-literate polity retains power, and is challenged by a politically weak, but educationally and economically privileged intelligentsia - a 'Decembrist' revolutionary situation. No nationalist problems and conflicts arise here, says Gellner ${ }^{32}$. In the last case, line 3, which captures early industrialism within a culturally homogeneous society, the power-holders are differentiated from the non-power holders by the former's monopoly of modern high culture. This situation gives rise to class conflict, which may be moderately ferocious, but without the catalyst of ethnic differentiation is not likely to be especially politically destabilising - contrary to the assumptions of classical Marxism. Again, for Gellner, this situation thwarts nationalist problems and conflicts.

The typology implies, by contrast, four forms of nationalism-engendering situations:

- satisfied nationalism, line 5, is characteristic of mature homogeneous industrialism in which the power-holders and non-power-holders share access to the same style of modern education, and are co-cultural co-nationals - in which case we can expect no [internal] nationalist conflicts and problems ${ }^{33}$;

- classical liberal nationalism, line 6, is characteristic of territories in which some have power and others do not, and this difference correlates with cultural differences, even though the relevant persons are both educationally equipped for modern society - a situation, Gellner suggests, which historically corresponds to the 'unification nationalisms' of nineteenth century Italy and Germany ${ }^{34}$;

- ethnic nationalism, line 4, is characteristic of territories in which power-holders have privileged access to the central high culture, which is their own, while the powerless are also the educationally deprived, sunk in low cultures. This scenario leads the small intelligentsias of the powerless to spearhead efforts to make their low culture into a high culture - a situation, Gellner, suggests, which historically corresponds to the nationalisms of Eastern, Slavic and Balkan Europe 35 ; and

- diaspora nationalism, line 7, which might be better described as 'middle-man' nationalism, arises in societies in transit from agraria to industria, and is characteristic of groups which previously had access to commercial and educational high culture, often through their casteroles as pariah 'middle-men' in the agrarian economy. These groups are economically better equipped for modernisation than others who have historically lacked access to a high culture, are ethnically distinctive, but lack political and military power. They are likely candidates for genocidal assaults or mass expulsions as economic competition grows within a modernising 
and nationalising polity - and in consequence, are likely to generate 'diaspora nationalisms'. Gellner has in mind the Jews, Greeks, Armenians, overseas Indians in Africa, overseas Chinese in south-east Asia, and the Ibos of Nigeria ${ }^{36}$.

This typology rests on a theory of social conflict, explicitly directed against Marxist propositions. Nationalist conflict is rooted in cultural heterogeneity, competition between differently or similarly educationally equipped peoples, and in inequalities in access to political power. Conflict is predicted to occur 'where 'ethnic' (cultural or other diacritical marks) are visible and accentuate the differences in educational access and power', and 'above all, when they inhibit the free flow of personnel across the loose lines of social stratification'37. In short: blockages in social mobility, when tied to ethnic or other diacritical markers, are at the heart of nationalist conflicts. I summarise his thesis as follows: exclusionary control of cultural capital, or usurpationary attempts to capture it, rather than exclusionary control of propertied capital or usurpationary attempts to expropriate it, are what gives rise to vigorous social wars, nationalist conflicts.

This theory of conflict is tied, in deliberately provocative language to a theory of 'social entropy' and equality in industrial society ${ }^{38}$. An ideal-typical industrial society should have a systematic randomness, and thus be 'entropic': it should not be one in which social origins matter in determining placement in the occupational and prestige hierarchies, and in this sense it should be egalitarian, committed to equality of opportunity. 'Entropy-resistant traits' constitute a very serious problem for industrial societies. They 'have a marked tendency not to become, even with the passage of time since the initial establishment of an industrial society, evenly dispersed throughout the entire society'39. Such traits can, be invented, Gellner suggests, to apply to a particular class of persons, but

'the entropy-resistance of a concept, in this sense, will normally be of interest only if it is a reasonably natural notion, one already in use in the society in question, rather than artificially invented for the present purpose (my emphasis). ${ }^{, 40}$

He then proceeds to discuss a range of entropy-resistant traits: physical or genetically transmitted traits and religious-cultural habits which are often just as resistant to the industrial 'melting pot'.

This discussion, while illuminating, sits uneasily with the arguments in Thought and Change which had suggested the almost plasticine materials with which modern nation-builders could 'invent' their nations and nation-states. Nevertheless Gellner restates his conviction that we cannot predict which cultures will be blessed with success in their efforts to become nationalist cultures with political roofs ${ }^{41}$. He goes further, and suggests that the 'weakness of nationalism', is much greater 
than it might appear at first glance ${ }^{42}$. The number of languages in the world may be some 8,000 , and the number of other cultural or historical materials which might be used to mark potential national cultures is even higher. Yet there is at present about 200 states in existence - many of which are postage-stamp states which cannot be counted as aspirant nation-states. The potential number of nation-states may be higher given the existence of numerous unsatisfied nationalism which may succeed, one day. However, the point is that the ratio of effective to potential nationalisms is a small one - much less than nationalists might imagine. The implication, although it is not spelled out, is that a blind, unpredictable and evolutionary process selects which nationalisms shall succeed, and which shall not, but we cannot be more precise than this. There is an apparent paradox here. Nationalism is a very strong force in the modern world, in most cases it prevails, and it does set the standard for what constitutes a modern state. However, very few potential nations are strong enough to make it to modernity and statehood.

$* * * * * *$

The Problems with Gellner's Theory: Criticisms and Reformulations.

Gellner's theory has been subject to diffuse criticisms, and the purpose of the remainder of this essay is to bring these criticisms together, to address how robust the theory remains in the light of these criticisms, and, not least, to see how the theory can be reformulated.

\section{The Philosophical Functionalism of the Argument.}

Gellner's theory, both in Thought and Change and Nations and Nationalism, seems to be explicitly, brazenly, and unashamedly, functionalist. Functionalism is characteristic of historical materialism ${ }^{43}$, and forgiveable in a social anthropologist, but it is less easily accepted by philosophers, political scientists, and other social scientists committed to causal explanations or methodological individualism. It is a nice irony that it is Perry Anderson, grandfather of the Marxist New Left, who complains that the 'most arresting feature of [Gellner's] theory of nationalism is its single-minded economic functionalism. ${ }^{34} \mathrm{He}$ cites in support a passage from the conclusion to Nations and Nationalism:

So the economy needs both the new type of central culture and the central state; the culture needs the state; and the state probably needs the homogeneous cultural branding of its flock .... In brief, the mutual relationship of a modern culture and state is something quite new, and springs, inevitably, from the requirements of a modern economy. 45 
There is no denying the functionalist cast of Gellner's arguments. However, if one is sceptical about functionalist arguments in the social sciences - as I am - the interesting question is whether Gellner's argument can be reconstructed in a non-functionalist manner. It is clear that for him nationalism is explained by its beneficial consequences (functionality) for modern society ${ }^{46}$. A formally and strongly functionalist version of his argument would go as follows $\mathrm{s}^{47}$ :

(1). Nationalism is an effect of modernisation.

(2). Nationalism is beneficial for modernising states - because a highly specialised division of labour requires a unified high culture, which is underpinned by a highly developed and specialised educational system.

(3). Nationalism (in Gellner's sense) is unintended by the actors producing modernisation.

(4). The causal relationship between nationalism and modernisation is not recognised by the agents operating in modemising societies.

(5). Nationalism functionally maintains modernisation by a feedback loop operating through the actions of modemising states.

Formulated in this way Gellner's argument displays all the vices of functionalist reasoning - in which events and processes occur which are implausibly treated as wholly beyond the understanding of human agents, in which consequences precede causes, and in which suspicions arise that supra-individual and holistic entities are being tacitly invoked to do explanatory work

One obvious way to reconstruct Gellner's argument is to deny (4), and replace a functionalist explanation a 'filter explanation.' 48 The relevant 'filter-explanation', close to Gellner's own discussions in Thought and Change and Nations and Nationalism, would take the following form: modernising élites believe that nationalism is essential for modernisation, precisely because it breaks down barriers to modernising success. In other words nation-building nationalists recognise the beneficial consequences of nationalism, and this fact helps explains its political implementation. Nationalists believe that nation-building will break down traditionalist or religious inhibitions on economic growth, and political blockages - such as imperialist domination or caste-like barriers which prevent the liberation of productive economic, political and cultural energies ${ }^{49}$. And it is not at all difficult to find wide-ranging support for this style of filter explanation. Prospective nationbuilders like Paidraig Pearse and Jawaharlal Nehru embraced nationalism, at least in part because they believed it would liberate the Irish and Indian nations, and free them to develop their educational, economic and political systems. The Japanese reformers of the Meiji restoration deliberately imitated features of German and French nation-building in their efforts to build a modern Japan. The idea that nationalism can lead to a renewal - or revival - of social energies was 
implicit in the advice rendered by Rousseau in The Government of Poland, which commended a citizen's army and a comprehensive state-controlled education system to the Poles 50 ..

However, although this 'filter explanation' avoids Gellner's strong functionalism it remains vulnerable, on two grounds. First, the 'real' filter in explaining the actions of the first nationbuilders and nationalists may well have been the perception that nationalism was essential for military success or geo-political security, rather than economic success - and therefore the historical relationship between nationalism, modernisation and industrialisation may have been more indirect and unintended than the Gellnerian model suggests. 51 . Secondly, the universal truth of the "filter explanation' may be doubted, i.e. nationalism may not be essential for modernising success. The state-socialist regimes - especially the USSR - did not rely centrally - although one might argue that they did rely tacitly - on nationalism for 'first-stage industrialisation'. Moreover, there have been some highly successful industrial city-states - e.g. Hong Kong - which have not required nationalism to travel to their version of modernity.

These qualifications, do not, however, imperil the general Gellnerian thesis that nationalism is beneficial, and even possibly optimal, for modernisation - providing we accept the qualification that this relationship is often widely recognised by nationalists themselves. It is ore thing to argue that modernisation produces mass literacy and a mass education system which together stimulate nationalism, it is quite another to suggest that the 'need' of the economy is for nationalism - which is then generated in an automatic functionalist response.

It is also tempting to draw a distinction between explaining the genesis of nationalism and explaining its diffusion. The genesis of nationalism may have been at least partially autonomous of modernisation and industrialisation - and its functionally beneficially consequences may only have been partially related to modern economic development. However, the diffusion of nationalism, its attractiveness to those who followed the first modern nations, may be more centrally linked to their belief in a Gellnerian-style filter explanation. Rather than being foolish victims of the contagious bad ideas, as Kedourie implied, nationalists believed that nationalism would assist the modernisation of their nations in the way that it had apparently aided the Americans, the French, and the Germans. In short, it is theoretically possible to argue for the core Gellnerian thesis, of a functional relationship between nationalism and modernity, without expressing it in a strongly functionalist form. That does not mean it is true. 


\section{The Place of Nationalism in a Philosophy of History.}

Delineating stages in history are partly matters of epistemic taste. Some completely reject the idea of a philosophy of history; not everybody likes three-stage models of human progress; and some prefer explicitly evolutionary to Gellner's non-teleological and episodic conceptions of the transitions between stages in human history. However even within Gellner's philosophy of history there are two potentially embarrassing questions:

- could there have been nations before nationalism, and, if so, can Gellner's theory cope with such anomalies?

- can there be post-industrial national conflicts, and if so, how do they fit in with Gellner's general theory ?

Nations before Nationalism ? Gellner's is a strongly 'modernist' theory of nationalism. His readers are plainly informed that nationalism only became an historical possibility from approximately the eighteenth century. Indeed he casts the philosophers of the Enlightenment in the role of the first alienated intelligentsia, as 'the westernisers of the west'. Readers are also firmly told that nationalism invents nations, rather than the other way around.

Yet a considerable number of specialists on nationalism, implicitly or explicitly, reject the stark modernism of Gellner and others. Thus it is standard for historians to write of the 'old continuous European nations', and to compare them with the 'new nations' of Eastern Europe and elsewhere in the world52. Historical sociologists write in a similar vein. John Armstrong's Nations before Nationalism and Anthony Smith's The Ethnic Origins of Nations, as their titles suggest, appear to be sustained criticisms of the modernist interpretation of nations and nationalism ${ }^{53}$. Smith, for example, argues that ethnic culture and social organisation were persistent, intensive, widespread and salient in much of antiquity and the medieval era, even if particular ethnic communities rose and declined over centuries. Moreover, particular kingdoms were often based on ethnic communities, and he argues that nationalism represents 'the transformation and universalisation of a pre-existing political and social norm.' 54 Similarly Liah Greenfeld's recent stidy, Nationalism, treats sixteenth-century England as the first nation and the site of the first nationalism, and her researches on England, France, Russia, Germany and America extend back to the Renaissance, let alone the Reformation ${ }^{55}$.

Can one defend Gellner's theory against these arguments? As we have seen Gellner anticipated one possible line of defence in Thought and Change: the forces of modernisation have been at work since the Reformation, or before. However, this reply is not very convincing, seems to operate against the placement of nationalism within Gellner's triadic philosophy of history, and would 
appear to suggest that Protestantism and vernacular print languages were more important than industrialism in explaining nationalism. It does seem sensible to concede that 'national consciousness' developed in some territories before full-scale industrialisation: consider just the colonies of Latin America, North America and Ireland. Moreover, it seems sensible to concede that proto-nationalist ideas existed, at least in embryonic forms, in commercial societies like early modern England and Holland 56 . This leaves Gellner with his other, and in my judgement theoretically more consistent, line of defence - to refuse to classify the phenomena of preeighteenth century ethnic or national consciousness with modem nationalism. There are at least two good grounds for doing so.

First, many of the authors who survey the rise of 'nations' before nationalism are conceptually confused; and, secondly, many of them concede that nationalism 'both as an ideology and movement, is a wholly modern phenomenon. 57 The conceptual confusions can be illustrated by considering Liah Greenfield's recently much-praised writings. The first page of her long work begins with a pre-commitment to confusion:

The word 'nationalism' is used here as an umbrella term under which are subsumed the related phenomena of national identity (or nationality) and consciousness, and collectivities based on them - nations; occasionally, it is employed to refer to the articulate ideology on which national identity and consciousness rest, though not - unless specified - to the politically activist, xenophobic variety of national patriotism, which it frequently designates. 58

This strategy casually elides the admittedly much-tangled concepts of nation, national identity, national consciousness, patriotism, nationality, and nationalism proper ${ }^{59}$. No wonder that 'nationalism' can be found in the 1500 s if one grants the term such empirical range. And it is true that the lay usage of the term has this wide range ${ }^{60}$. However, Gellner's theory can not be embarrassed by the existence of the word nation in pre-eighteenth century England, or even by presence of national consciousness - especially of a religiously mediated kind - although it would be embarrassed by explicitly nationalist doctrines, programmes, and movements flourishing in the time of Henry VII.

Greenfeld, however, is not untypical in these confusions. Most of those who discuss 'nations' before 'nationalism' are in fact establishing the existence of cultural precedents, and ethnic and other materials, which are subsequently shaped and re-shaped by nationalists in pursuit of nationbuilding. However, it is a conceptual confusion, or so at least a Gellnerian must insist, to assimilate the materials upon which nationalists will draw, to nationalism itself. Consciousness of a shared cultural, religious or territorial identity is not of the essence of nationalism. That said the work of 
Armstrong, Smith and Greenfeld may be used to qualify Gellner's work in one key respect: they furnish evidence for the proposition that the first nations were innovations rather than inventions, and that predicting or 'retrodicting' which nations would emerge within the age of nationalism may be less difficult than Gellner declares.

It is just as important to recognise that most of those who have written of nations before the age of nationalism, whether they be historians like Seton-Watson, or historical sociologists, like Armstrong, Greenfeld and Smith, concede the modernity of nationalist doctrine and nationalist political programmes. They recognise that the writers of the Enlightenment and their romantic critics, and the phenomena of the American and French revolutions, produced an explicitly modem and novel set of political doctrines which were nationalist proper. For these reasons the Gellnerian theory can be saved: there may have been talk about nations and indeed national consciousness before nationalism, but, so to speak, there was no nationalist talk of nations and national consciousness before nationalism. However, that said, Gellner is left with the problem that the historical evidence does not suggest a neat relationship between industrialisation and the onset of nationalism.

Nationalism after Industrialisation? Another possible general embarrassment for Gellner's philosophy of history, and one which has often been cited in seminar-folklore, is the evidence of revived or new nationalist secessionist movements emerging within a fully industrialised environment, after the 'great transformation' from agraria to industria has been completed. The question here is whether ethnic revivalism, 'ethnonationalism', 'mini-nationalism' or 'neonationalism' in advanced OECD countries, and the new nationalisms among and within the postSoviet successor states, constitute an embarrassment for Gellner's theory.

Firstly, it is not at all clear how exactly such evidence would refute the theory. Although at odds with the tone of the argument in Thought and Change it is consistent with some of the propositions in Nations and Nationalism. In the latter Gellner clearly differentiates between early nationalism and late nationalism - which occur in the conditions of early and mature industrialisation respectively ${ }^{61}$. In early industrialism there is 'a terrible difference' between the life-chances of the well-off and the starving poor, whereas in late industrialism there is not such acute objective social discontent - and, in consequence, although a late nationalism may be motivated by barriers to social mobility and inequality, it will, on materialist assumptions, presumably, be less virulent. The upshot is that Gellner's theory would be most embarrassed by virulent nationalist secessionisms within advanced 'industrias', not by the existence of such movements themselves which, after all, might be occasioned by 'counter-entropic' traits. Gellner, it seems, is presumed 
to have argued that the world is drifting towards advanced industrialised homogeneous nationstates in which nationalist secessionisms are less likely - and that is one possible reading of his reflections on the 'future of nationalism'62. However, a moment's reflection should make clear that an industrialised world characterised by differential demographic growth-rates across culturally differentiated communities, displaying counter-entropic traits of whatever kind, and large-scale migratory movements - in which migrants can retain their original high culture (if they have one) is not going to be free either of nationalist secessionist possibilities, or for that matter of 'integral nationalisms'. Consequently, even if Gellner himself can be convicted of the view that nationalist secessionist movements are less likely after industrialisation - which I doubt - his theory itself is not deductively linked to such a view.

Another line of defence would maintain that in any case the scale of the ethnic revival, or nationalist secessionism, or nationalist irredentism, at least within the countries of the OECD, has not been very substantial. There are no significant secessionist or irredentist movements in Austria, Australia, Denmark, Iceland, Luxembourg, Japan, the Netherlands, Norway, New Zealand, Sweden, Switzerland or the USA. There are significant 'regionalist' or 'devolutionist' movements in Wales within the United Kingdom, in Catalonia in Spain, in Britanny and Corsica in France, and amongst both linguistic communities in Belgium. There are also significant, but so far extremely peaceful secessionist movements in Canada, amongst the Québecois, and in Great Britain amongst the Scots - who seek independence 'within' the NAFTA and the EU respectively. There has also been a recent effervescence of what may become full-fledged secessionist or just simply regionalist sentiment in Italy, notably in 'Lombardy'. Germany has been unified, but has officially abandoned all its other possible irredentist ambitions. Within 'western Europe' only Greece, the Republic of Ireland, and possibly Finland display possible ambitions to complete their nations, and in each case, the support for national 're-unification' is generally peaceful, sentimental and inactive - which is not to say that it is finished ${ }^{63}$. Significant cases of violent secessionism in Europe exist within Northern Ireland and the Basque country, but even here the relevant movements have smaller support-bases than their peaceful and regionally inclined competitors. The two Cypriot communities are, however, undoubtedly capable of further war.

In short, there is not a great deal in the European Union, or the OECD, for Gellner to be embarrassed about, even if the relevant charge against him was accurate. ${ }^{64}$ The cases of extensive armed violence and insurrection by aggrieved nationalist groups within the OECD are few: Basque separatists in Spain; Irish republicans and loyalist paramilitaries in Northern Ireland; Israelis and Palestinians in and outside of Israel/Palestine. Secondly, in many cases the aggrieved ethnic communities would appear to be capable of being satisfied by public policy changes and/or 
constitutional changes which recognise their national cultural claims: the Québecois in Canada, the Scots and Welsh in the UK, the Walloons in Belgium, the Catalans in Spain. A similar argument may be advanced for the bulk of Basques and Irish nationalists in Northern Ireland: Basques will be satisfied with extensive autonomy, northern Irish nationalists by a British-Irish condominium ${ }^{65}$. Many minority nationalisms in industrialised states are often less than separatist and display clear signs of being instrumentally oriented. Moreover, many of the actual or potential national and ethnic conflicts in advanced industrial countries, in principle, may be remediable by some effective conflict-regulating practices, such as consociations, federalisms, and condominiums - a point on which Gellner is weak, and to which I shall return. But the scale of the nationalist secessionism amongst advanced industrialised liberal democracies does seem exaggerated.

The success of nationalist secessionism within the industrialised states of what were the Soviet Union and Yugoslavia is a fact; and there are further secessionist movements within the debris of these former communist systems: in Nagorno-Karabakh, Abkhazia, South Ossetia, Dniester, Gagauzia, Chechen-Ingushetia, Kaliningrad, Crimea, Krajina, Kosovo and the Vojvodina. These phenomena are, however, not an overt embarrassment for Gellner's theory - unlike some other theories ${ }^{66}$. These two major communist systems failed to invent durable Soviet and Yugoslav nationalisms or 'high cultures', but they did industrialise through adapting - and in some cases creating - national cultures, and, incidentally, national political units, which then, in most cases, became the bases of secessionist movements when the communists lost their grip on power, which in turn was connected to failures in managing industrial performance. This said, not all of the conflicts which generated secession from these communist polities are explicable within the Gellnerian theory of nationalism - which, as presently formulated, cannot treat sensitively the importance of the state-system and political regime-types in explaining what encourages or thwarts nationalist secessionisms.

A superfluous defence of the Gellnerian theory of nationalism is also available: most other social and political theories are put in a much worse state by evidence of nationalist secessionism in industrialised societies. There is an embarrassing affinity between Marxists who thought the future age of statelessness was also to be an age of nationlessness, when we were all expected to be classless and culture-less or perhaps mono-cultured in a multi-cultured way, and liberal functionalists who anticipated that the outcome of modernisation would be an instrumental and cosmopolitan world-federal order rather than a world of nation-states, that ideocracy would vanish beneath the benefits of affluence, and that the fate of the nation-state was to be undermined from above, by international organisations, and from below, by political decentralisation ${ }^{67}$. 


\section{How predictionless or retrodictionless is the theory?}

Gellner explicitly rejects the idea that one can predict which nations will acquire political roofs in the course of modernisation, and, by implication, that we can predict just which phenotypically or culturally counter-entropic traits, or other materials, will provide the markers for the nations built by nationalists.

There are at least two difficulties here. First, the selection process which determines just which of the thousands of potential nations will become members of the United Nations may not be as blind, or as unpredictable, as Gellner suggests. Secondly, if 'invented' or 'designed' nations are less stable than the 'old' or 'continuous' nations such evidence would suggest that 'real' ethnic or other foundations, of some kind, are more vital than Gellner suggests to the success of nationbuilding. I shall only elaborate the first point.

Most of us can accept that while many may be called to be nations only a few are chosen. However, Gellner's own theory, in principle, has greater 'retrodictive' potential than he implies: his own theoretical suppositions point towards a key selection-mechanism. Ceteris paribus, those possessed of a high culture, or on the verge of possessing one on the eve of modernisation, should be better endowed with nation-building potential than other potential nations. After all those who have no 'high culture', or potential 'high culture', presumably are bereft of an intelligentsia, and lack the requisite quota of poets, balladeers, bibliophiles, engineers and officers for successful nation-building. For this very reason Gellner's casual citation of the nationalist potential implicit in the existence of 8,000 languages should not be accepted at face-value. How many of the world's alleged 8,000 languages have had the capacity for rapid transformation into a high culture, i.e. one with an extensive vocabulary, a formal grammar, an alphabet, a literary tradition, a capacity for context-free communication, etc? In principle, this question is open to empirical resolution. My hypothesis would be that the number of feasible potential nations on the eve of modernity was less than a fundamentalist Gellnerian would imagine - but I have not carried out the requisite empirical work.

A Gellnerian should also assume that viable candidates for nationhood must have a threshold population of around 250,000 - roughly the population of Iceland which has successfully produced a national high culture - on the grounds, suggested in Thought and Change, viz. economies of scale are required to sustain a 'non-parasitic' and modern, education for a high culture. If so, then surely the numbers of potential nationalist 'peoples' on the eve of modernity was less than Gellner implies? This question is also capable of empirical resolution through appropriate investigation of demographic and anthropological data. 
Empirical appraisal of the merits of the selection-mechanism implicit in Gellner's theory need not, of course, be confined to the linguistic and demographic properties of a potential nations. Gellner explicitly recognises in Nations and Nationalism that those communities which are tightly integrated into a literate world-religion are far more likely to be candidates for successful nationbuilding or secessionist movements than those which are not. In short, on the logic of Gellner's own theory, one should predict greater nation-building capacity in some pre-modern cultures than others, and on his own assumptions one would expect the number of feasible nations on the eve of modernity to be less numerous and more predictable than he implies. This argument is one way of reconciling Gellner's general theory with the arguments advanced by the 'nations before nationalism' school of Armstrong and Smith.

However, if one was to extract from the mechanism of possession of a proto-high culture possible retrodictive or predictive hypotheses about which cultures are most likely to generate modern nations, and test them against the historical evidence, one would run into the issue of rival 'selection mechanisms', which may have been, and may continue to be, just as significant as that implicit in Gellner's theory. The most obvious alternative selection mechanism affecting which cultures become nations is exogenous rather than endogenous. Since the onset of modernity whenever that was - the state-system and the great powers have often been decisive arbiters of the prospects of nations' prospects achieving statehood or autonomy. The four great waves of modem state-creation have accompanied the collapse or weakening of empires: the formation of the states of Latin America in the 1820 s and after, the new European states recognised at Versailles, the new Asian, African, Caribbean and Pacific states established after 1945; and the new successor states established on the ruins of the former Czarist and Soviet empires after 1989.

[tabular data on empires and the dates of nation-state formation

to be inserted here]

Most nations, to the extent that they are nations, owe their existence, or at least their territorial shape, to the calculations, decisions and indecisions of the remaining great powers when another great power is collapsing or weakening. Even if all the Gellnerian ingredients of blocked social mobility and strong diacritical markers are present a potentially secessionist nationalism may be prevented from being successful by its exogenous environment. 'Nation-state' formation frequently takes place, as it were, by permission, rather than as a by-product of the strength of indigenous mobilisation for nationhood. Thus the French helped the birth of the American nation, the British empire hastened the collapse of the Spanish empire, the victorious Allies decided the fate and shape 
of 'nations' at Versailles, and the departing colonial powers shaped the frontiers of the new 'nations' (in fact multi-national states) which they left behind. Great powers have frequently played a critical role in determining the success or otherwise of secessions and nation-foundation, whatever the militaristic or revolutionary propensities of nationalists. Thus the principle of selfdetermination was widely ignored by the great powers after World War 1 because they wanted to create economically and strategically (rather than nationally) viable states as checks and balances on Germany and the Soviet Union. The boundaries of Hungary, Poland, Romania, and Yugoslavia in the inter-war years were established with scant respect for ethnic boundaries. The plebiscite was used to establish local preferences in some frontier zones, but not in geopolitically significant territories like the Sudetenland or the South Tyrol. Subsequently, from 1948 until 1989, the superpower system also functioned to preserve borders which make no sense on any reasonable construal of the principle of 'self-determination.'

It also seems reasonable to suggest that proto- or embryonic nations which enjoy strategic positions or resources - be they demographic, military or economic - within collapsing empires are also likely to do better than more marginal communities, which in these scenarios may face the threat of genocide, mass-population transfers or coercive assimilation. In short power-politics, or power-resources, provide an alternative (or at least a supplementary and over-determining selectionmechanism) to that implicit in Gellner's theory. This criticism of Gellner's theory. highlights its apolitical nature.

\section{The Typology and Forms of Nationalism.}

Gellner's typology is an admirable effort at theoretical parsimony. Three dimensions are used to generate four types of nationalism: western liberal nationalism, ethnic nationalism, diaspora nationalism and mature homogeneous nationalism. However, there are problems with the typology, even if we leave to one side the simplicity of the dimensions.

First, its explanatory capacities are implicitly limited to nationalist conflicts within states; it has little to say about nationalist conflicts between states. Secondly, it is not clear that classical liberal western nationalism emerges from the conjunction of a clash between educated power-holders from one high culture facing educated non power-holders from another high culture, whereas ethnic nationalism emerges from a clash between educated power-holders from one high culture facing uneducated non-powerholders from a low culture. Gellner cites as the classic exemplars of classical liberal western nationalism the 'unification nationalisms' of Italy and Germany, and suggests that 'a few battles' and 'some diplomacy' were all that were required to sort out the right political roofs for the previously subordinated high cultures. By contrast, in Eastern Europe and the Balkans 
matters were much messier, because nationalism was mobilised behind 'a high culture as yet not properly crystallised' which made matters a great deal more ferociously 'ethnic' - population expulsions, liquidations, coercive assimilation and other horrors occurred. Although Gellner euphemistically recognises the 'markedly un-benign'68 forms German and Italian nationalisms took in the twentieth century he does so in a parenthesis which almost suggests that it is a problem for John Plamenatz - who developed one form of the contrast between western and eastern nationalisms - rather than for him ! German and Italian nationalisms were markedly 'un-benign' in frontier-zones. Indeed the German variety notoriously excelled Balkan nationalism in its bloodthirstiness. This gaping difficulty suggests that the important difference between ethnic (or Habsburg) nationalism and classical liberal (or western) nationalism is not the availability of a high culture functional for modernity in the latter case but not in the former, but, amongst other things, the fact that in the Habsburg-type of nationalism there are multiple and roughly equal but intermixed and counter-entropic cultures (i.e. B1, B2... Bn), whereas in the classical liberal case the $B$ group can feasibly assimilate or homogenise all the possible other Bs in its nation-building ambitions. The complaint here is that the typology is being used to generate 'types' which do not follow logically follow from it. Classical liberal 'western' nationalism may be more likely in certain territorially favourable bi-cultural conditions, whereas 'eastern' ethnic nationalism may be more likely in multi-cultural conditions. The typology is only useful for considering 'homogeneous' and 'bi-cultural' situations; it cannot, by definition, be used to explain 'multi-cultural' situations ${ }^{69}$. The typology is also a typology of cultural nationalisms, rather than a typology of political nationalisms, which have been far more common in the literature on the subject ${ }^{70}$. And precisely because they are bereft of political content- other than a very crude distinction between powerholders and non- powerholders - it is difficult to assent to Gellner's illustrations of his 'types'. For example, exclusionary and integral nationalisms (which have strong ethnic content) have developed amongst peoples possessed of a high culture in combat with those who also have a high culture; while inclusive and civic assimilationist nationalisms have developed amongst peoples who have not had a crystallised high culture but have been engaged in combat with those who have a high culture.

\section{The Apolitical character of Gellner's theory.}

Gellner's theory of nationalism rests on cultural and materialist premises. What it lacks is a sustained and developed sense of the political - apart from his perception of the precariousness of western liberal pluralism and his preparedness to give retrospective thanks to nationalism for preserving it - albeit as an unintended consequence. 
I shall substantiate the apolitical charge against Gellner's formulation of his theory in several ways. First, his typology is geared towards explaining the development or thwarting of nationalist secessionism, but it does not provide a politically sensitive account of what may dampen nationalist secessionism. Secondly, the theory relies on culturally or materially reductionist accounts of political motivation. Thirdly, in explaining nationalism, we have already seen that Gellner neglects the role of power-politics in explaining which cultures become nations, and the possibility that nation-builders explicitly see the functional relationship between nationalism and modernity which he posits. Fourthly, although he sees the connections between nationalism and egalitarianism in modern societies, he does not, strangely enough, see the mutually reinforcing relationships between nationalism, egalitarianism and democratisation. Finally, and relatedly, he displays contempt for nationalist doctrines.

(i)

Gellner's typology is geared towards explaining the development or thwarting of nationalist secessionism, but does not provide a politically sensitive account of what may dampen nationalist secessionism. It assumes that the range of possibilities in modern times is bifurcated to a simple choice between nationalist homogenisation through assimilation and nationalist secessionism which produces another nationalist homogenisation: 'Nowadays people can live only in units defined by a shared culture, and internally mobile and fluid. Genuine cultural pluralism ceases to be viable under current conditions. ${ }^{2} 71$

This argument is not tenable, unless it is rephrased as an equilibrium theory, in which homogeneous nationalism is the most stable outcome in modern times, the systemic equilibrium, so to speak. It is true that in modern times political units have frequently adopted what John McGarry and I call strategies for eliminating national and ethnic differences, through four key devices: (i) genocide, (ii) mass-population transfers, (iii) territorial restructuring through partitions/secessions, and (iv) cultural engineering in the form of integration or assimilation ${ }^{72}$. The widespread use of these strategies in our times confirms the intuitive sense in Gellner's idea of a nationalist homogenising tendency at work within modern societies. Yet one initial qualification must be made: political integration of diverse peoples often occurs without full-scale cultural assimilation, which suggests, once more, that Gellner too easily assumes that a political nationalism must be a (high) cultural nationalism. More importantly political entities in modern times have also developed strategies for managing national and ethnic differences which, prima facie, counteract the potency of the homogenisation process implicit in Gellner's theory. We have distinguished four ways in which genuine cultural pluralism (if not democracy) appears to operate: (i) control; (ii) arbitration, (iii) federation and (iv) consociation ${ }^{73}$. Throughout modernity these types have existed at various 
times, and in many parts of the world, and new versions of them are continually springing into being: thus Belgium has recently federalised, and the European Union is arguably an increasingly embattled consociation, threatened by the ambitions of both federalists and secessionists.

There are, however, arguments which suggest that all four ways of managing ethnic and national differences, or systems of cultural pluralism, are less stable than homogeneous nation-states. Systems of control, like empires, communist dictatorships, and majoritarian democracies or 'ethnic democracies' as some prefer to call systems dominated by a StaatVolk, have shattered in many places, and an orthodox Gellnerian might, reasonably, classify them as 'hang-overs' from 'agraria' succumbing to modernising pressures, albeit belatedly. The break-up of Ethiopia might be considered an exemplary illustration. External and internal arbitrations of ethnic conflicts are also infrequently successful ${ }^{74}$. Democratic bi-ethnic or multi-ethnic federations are few and in regular crises. Czechoslovakia broke up very quickly after democratisation. Consociations frequently break down, and when they are successful, they can lead to integration and assimilation, as some believe has occurred through 'depillarisation' in the Netherlands. However, the persistence of such entities are empirical embarrassments for Gellner's theory: Switzerland is a real anomaly. Multi-ethnic and multi-national states in which there is a common sense of political (not cultural) nationhood exist. Some would even argue that Gellner lives in one. The key point is that Gellner's theory too readily assumes that the general case, that the political nation and the cultural nation must be one, is the universal and, in the long run, the irresistible tendency. While Gellner admits that nationalism is 'occasionally defeated by some other force or interest, or by inertia'75 he leaves no room whatsoever for the creative possibilities of political design and architecture. Constitutional and political engineers do not figure in his sociologically reductionist conception of modernity.

Although he explicitly denies it, Gellner's relies on culturally or materially reductionist accounts of the political motivations which produce nationalism. He does defend himself against the thesis that he is economically reductionist - suggesting that it is a parody to claim that the nationalist footsoldier is fighting for his tobacco shop pension. Nevertheless the impression conveyed in both Thought and Change and Nations and Nationalism is that job-hunting and job-deprived intelligentsias and proletarians provide the nationalist personnel - a thesis which he does not empirically substantiate.

Gellner also recognises that a range of cultural humiliations and repressions may provoke nationalist protests and insurrections. However, once experience of repression, as opposed to 
blocked social mobility, becomes a key variable in explaining the propensity to engage in nationalist movements we have moved some distance from the logical underpinnings of Gellner's theory in industrial society. A political regime which is flexibile, and non-repressive, and has politically pluralist characteristics, may be able to thwart secessionist pressures - precisely because it gives the culturally differentiated, and possibly the educationally differentiated, some share in political institutions. In short it may be the political position within which national minorities operate, rather than their material or cultural grievances, which best explains their predispositions to be secessionists, federalists, or consociationalists.

(iii)

In explaining nationalism we have already seen that Gellner underplays the role of power-politics in explaining which cultures become nations, and the possibility that nation-builders explicitly see the functional relationship between nationalism and modernity which he posits. He sees nationalist politics as the superstructural by-product of cultural fissures in turn shaped by the uneven diffusion of industrialism. In addition, it is clear, from the writings of numerous scholars that the genesis of nationalism, and indeed its maintenance, owed much to the functional relationship between nationalism and military success whatever about economic performance. The education and cultural standardisation of troops in the European ancien regime preceded that of the general citizenry. There is more than humour in the thesis that a language differs from a dialect in that the former has an army and a navy. In addition the state bureaucracies of the old European regimes were mechanisms for the genesis of nationalism - partly through the Gellnerian mechanisms of the development of a widely literate society, the decay of sacred religious languages and their replacement with vernacular high cultures produced by a new clerisy, the meritocratic bourgeoisie. The point is that state elites deliberately used nationalism, or at least proto-nationalism in the form of a membership of shared political community, for political purposes which operated autonomously from the logic of industrial society.

(iv)

The connections between nationalism and egalitarianism in modern societies are clearly and persuasively seen by Gellner, but he does not, strangely enough, spell out the mutually reinforcing relationships between nationalism, egalitarianism and democratisation. The first political nationalisms in the USA and France were explicitly democratic in character, and there are social structural arguments in the modernisation school which explain why the wider distribution of power-resources in modern societies has made democratic outcomes more likely than in feudal societies ${ }^{76}$. Preoccupied with the notion of the miracle of western liberalism Gellner has operated with the assumption that democratisation has been a lucky accident in some industrialised societies, 
rather than a systemic trait within such societies. However, it is odd to take the view that nationalism is no accidental by-product of modernisation and to claim that it is intrinsic to its more egalitarian conditions, and not to notice that exactly the same arguments can be made about democratisation. Moreover, the relationships, politically and culturally, between nationalism and democratisation, at least at the doctrinal level are very clear, or, at least, so I wish to maintain.

(v)

Gellner rightly maintains that it is central to nationalism that it holds that nations should be ruled by co-nationals. I would add that it is central to liberal nationalism that that should be the case with the express consent of the co-nationals. Although Gellner is able to see many reasons why liberals should adopt a positive attitude towards nationalism he fails to emphasise that there are many consistent nationalists who hold that all nations should be free, free to express themselves, culturally and politically, and, at least in liberal versions of this doctrine, that this freedom is consistent with, and constrained by, other nations' rights to the same cultural and political freedom. Nationalism can therefore be a liberal political doctrine, one which emphasises freedom, and it is one with at least the following political corollaries:

- the belief that all people are or should be members of nations;

- the belief that membership of a nation is a beneficial good;

- the belief that nations are the most important cultural and political collectivities;

- the belief that all nations have the right to determine their form of self-government and, relatedly,

- the belief that all nations have the right to self-determination; and finally

- the belief that the structures and activities of states should be subordinated to nationalist principles.

All these political implications of nationalist doctrine may seem obvious. However, Gellner, like most post-war academic commentators on nationalism, refuses to treat nationalism seriously as a political doctrine. Unsurprisingly he shares the anti-nationalist animus of the European intelligentsia of the diaspora who matured during or after the Nazi holocaust, although he does so with greater detachment and hard-headedness. He happily concedes to cosmopolitan critics of nationalism that nationalist authors are either self-evidently vacuous or incoherent.

His theory of nationalism is therefore vulnerable to the charge of presenting an entirely reductionist account which ignores the autonomous significance of politics and political doctrine in shaping social life. Nationalist political doctrine is not merely not vacuous, all self-professedly modern political doctrines, whether they be liberal, socialist or conservative are generally parasitic upon 
nationalist assumptions. Nationalism, with qualifications, is also a defensible doctrine for modem liberals, and therefore there is no necessary reason why someone convinced of the explanatory merits of Gellner's account of the sociological roots of nationalism must share his contempt for nationalist political doctrine.

Let me first demonstrate Gellner's contempt for nationalist doctrine. He suggests that nationalism has received relatively little attention from academic political philosophers because 'there was not enough in the way of good doctrines and texts, which is the kind of material they used to like, for them to get their teeth into'. In any case, even if they had, nationalist thinkers could not really have made much difference: 'If one of them had fallen, others would have stepped into their place'. He terminates by baldly declaring that 'their precise doctrines are hardly worth analysing', and that since nationalist ideology 'suffers from a pervasive false consciousness ... we shall not learn too much about nationalism from the study of its own prophets' 77 .

This style of argument is characteristically provocative. ${ }^{78}$ Gellner tells his readers - we, the reading intelligentsia - that nationalist thought is not worth examining, and does so in much the same manner that philosophers of the Enlightenment, and Marxists, held that religious doctrine was not worth examining because it represented an inchoate mixture of myth, superstition, error and false consciousness. The genesis of Gellner's first writings on nationalism lay in his. rejection of Elie Kedourie's argument that nationalism is a set of bad ideas which have resulted from a collectivist perversion of the idea of personal freedom or self-determination. Gellner's criticism of Kedourie is just like Marx's criticism of the philosophes - do not waste one's breath examining the bad ideas themselves, simply seek to explain their roots. Kedourie erred in treating (allegedly superstructural, or epiphenomenal) political ideas seriously, instead he should have decoded them as the inevitable by-product of (structural or essential) social forces. Gellner thus presumes that nationalist ideas are bad, or low-brow, and that they are epiphenomenal.

Gellner is conveying a clear message - he has no wish to disturb the bad press which nationalists' writings have received. This bad press holds nationalism responsible for many disasters and catastrophes, wars, forced mass-population transfers, imperialisms, fascisms, and genocides. Depending on the particular intellectual's theory of the source of all evil nationalism is held to be an expression of patriarchy, capitalism or socialism: feminists interpret nationalism as a by-product of patriarchal thought, penile aggression, and other features of male malevolence; socialists, especially Marxists, hold capitalism culpable for nationalism; while economic liberals generally see nationalism as a species of socialism because nationalists demand public regulation of capital and labour markets and are critical of the Ricardian theory of free trade. 
One reason Gellner has not taken nationalist doctrines seriously is that there have been few universalist theorists of nationalism, and those that have existed, like Jean-Jacques Rousseau and John Stuart Mill have usually been read, criticised and admired for their non-nationalist writings. Moreover, universalist themes in nationalist authors, like Edmund Burke, Johann Herder, Johann Fichte, and Friedrich List, have generally been seen as motivated by the particularist concerns of their own national cause ${ }^{79}$. The parochial audience to whom exponents of nationalism have addressed themselves has meant that their writings and arguments are not treated with respect by cosmopolitan intellectuals addressing other cosmopolitan intellectuals. This cosmopolitan bias against nationalist writing is something one should never forget.

However, rather than take readers through Rousseau's Social Contract or his Government of Poland, and rather than discuss Burke's views of political obligation, Herder's theory of language or Fichte's Addresses to the German Nation I shall try to elaborate briefly on what is liberal nationalist doctrine, and ask whether it is any less coherent or more vacuous than liberalism, conservatism or socialism. Nationalism is a prescriptive doctrine. Although it often comes packaged with fairy-tales these myths are no more or less plausible than the myths of social contracts, of class struggles, of wars between the sexes, of immemorial traditions of intimations, or of natural harmony of interests which characterise other political doctrines.

Nationalism is, firstly, the doctrine that nations should be free. The core idea here is simpleenough. Nations should not be oppressed by other nations, empires or polities - and by implication nations should not oppress other nations or establish empires. The more sophisticated idea is that nations should be free to choose their form of government, their public policies and to develop and express their material and cultural interests and values. This idea does not mean that all nations must seek to have their own states, and that all states have to be mono-national states - although there have been and there are nationalists who believe this vulgar version of the doctrine. What is fundamental to coherent nationalist doctrine is that members of the nation must consent to the form of government under which they live and express themselves, because without such consent they would not be free. In other words the prescriptive core of nationalist doctrine is co-terminous with the prescriptive core of democratic theory - with this important exception: nationalism defines the people or the demos in a way which democratic theory, left to its own devices, never can.

When I have argued this idea on previous occasions I am usually met by card-carrying cosmopolitans who ask: but what about Serbian nationalists ? or German nationalists ? or Turkish nationalists? or British nationalists ? or Canadian nationalists? What about 'integral nationalists' ? 
Do not these nationalists in practice seek the freedom of their nation at the expense of other nations ? The answer to this characteristically cosmopolitan objection to nationalist doctrine has been put nicely, by Brian Barry:

Particularistic nationalism bears the same relation to universal nationalism as selfishness does to individualism, selfishness being the pursuit of one's own interests without regard to the interests of others, and individualism being the doctrine that it is legitimate to pursue one's own interests on the same terms on which others are free to pursue others ${ }^{80}$.

Nationalism is most famously associated with the doctrine of national-self-determination, which it is fashionable to scoff at as chaotic or incoherent. No nationalist idea attracts such scorn from cosmopolitans and conservatives - who in this instance can be taken as equivalents ${ }^{81}$. However, the idea is simple enough, and related to the first one: a nation must be free to establish its preferred form of government, whether that be as a constituent component of a multi-national state or federation or as an independent state. (Gellner mistakenly implies that only separatist or irredentist nationalisms are proper nationalist movements).

The idea of national self-determination is attacked as meaningless, or dangerous, or dangerous and meaningless, because (a) it spells chaos to the world's map-makers, (b) it threatens the permanent instability of frontiers ${ }^{82}$; and (c) it fails to specify who constitutes the 'self' with the right to selfdetermination. The idea of self-determination is not, however, meaningless - although it is one, which if properly respected, would spell the destruction of many states which deserve to be destructed - if I may be permitted to be ungrammatical. It is true that as understood by many socalled international lawyers the idea of self-determination is meaningless ${ }^{83}$. As understood by socalled public international law between 1945 and 1989 self-determination is something which can be exercised only by 'the people' of an existing state or 'the people' of a territory which is about to become the former colony of a powers - and they can exercise this power but once. Properly understood, however, the doctrine of self-determination is a recursive principle of democratic consent: every nation should have the right to seek self-determination, including the right to secede to create its own state, providing the members of the nation consent to such self-determination, and providing they grant the same right to those who do not regard themselves as part of the nation concerned 84 .

Cosmopolitan critics will instantly jump in with searching questions: 'who are the people ? what if there is more than one nation in a given region? how does one ensure that each nation is granted self-determination in territories where nations are intermingled ?' These are important questions, especially in particular cases of national conflict, but they do not demonstrate the incoherence of the idea of national self-determination. All that these questions suggest is that implementing the idea of 
self-determination may not be easy. Observe that liberal, socialist, conservative and feminists have difficulties with working out the implementation of their core ideas, so nationalists are not alone in having problems with their doctrines. Note, secondly, that there are ways in which multiple nations may grant one another free and equal self-determination - for example through consociational or federal arrangements, or even through agreed partitions and negotiated exchanges of populations - so that the nationalist does not have to concede the unworkability of the idea of 'self-determination within self-determination'. Indeed the nationalist can agree with John Stuart Mill that there are cases where nationalities are so intermingled that the nations concerned must make a virtue of necessity by developing appropriately complex forms of political accommodation and respect, such as democratic condominia ${ }^{85}$.

Nationalism implies that all human beings should have one primary national loyalty, and it is often taken to imply that loyalty to the nation should be the first virtue of a citizen. This idea has internal and external implications. Internally it suggests that loyalty to the national community should transcend loyalty to more particular identifications, whether they be cultural, economic, or political, and externally it suggests that members of one's nation have higher moral claims than members of other nations. Now whatever may be said of the merits of such thinking, and note carefully that I am not personally endorsing it is scarcely fair to say that it is incoherent. Nationalist moral doctrine, as Barry points out, is certainly is at odds with cosmopolitanism - the doctrine that you owe equal duties to all members of the human species - and with personalism - the doctrine that you owe first moral obligations to your personal friends ${ }^{86}$. It is also at odds with the doctrine of statism - that your first loyalty is to the state - except, of course, when one's nation is a nation-state. When surveying the field of moral doctrines it may fairly be said that cosmopolitanism, personalism, statism and nationalism have all attracted rational arguments and exponents - and it is not credible to insist that of these four possible positions only nationalism is incoherent. It is, after all, a widely observed historical fact that people in practice have usually circumscribed their universe of moral obligations or their universe of social justice - and it is not flatly obvious that its is incoherent to believe that the primary universe of moral obligation should be the nation. Moreover, such nationalist thinking is not incompatible with the belief that nations may be duty-bound towards other nations - to observe genuine international law or to provide charitable assistance to other nations and so on. Note once again I am not endorsing such thinking merely suggesting that it is not meaningless. In brief, my argument is that nationalism, or at least liberal nationalism, is not deserving of the contempt with which Gellner wishes to be associated.

Nationalism, far from being vacuous has prescriptive public policy content, independently of particular political ideologies, like liberalism, socialism or conservatism. First, and most obviously, 
nationalism suggests a doctrine of citizenship. Who should and who should not automatically be entitled to membership of the nation ? Nationalists vary in their answer to the question, depending on the stress they give to ethnic or civic conceptions of the nation, but at least they provide an answer. Liberals, socialists and conservatives in practice accept the nationalist answer or debate its frontiers - but in practice rarely embrace the implications of full-blooded cosmopolitanism - if you'll forgive the loaded metaphor. The nationalist theory of citizenship is in turn closely bound to the development of what is called the modern welfare state - in which, in principle, co-nationals are treated as members of a collectivity engaged in mutual insurance and assurance. Secondly, nationalism, as Gellner emphasises, has prescriptive implications for national education - educating potential citizens in a national culture, in respect for nationally endorsed civic and or ethnic institutions, in prescribing the moral universe of rights and obligations, in preserving and developing distinctive cultural idiosyncrasies, and in freeing the educated from the prejudices, be they patriarchal or otherwise, of the home or the sect. Thirdly, nationalism normally puts clear limits on the operation of free-market economic policy by policy-makers. Nationalists rarely believe in the unrestrained movement of labour, though they may embrace the free movement of capital ${ }^{87}$. Nationalists are anti-Smithians - Adam not Anthony - in that they seek to inhibit particular consequences of homogenising capitalism, or for that matter of homogenising cosmopolitan socialism. They have in the current parlance communitarian values which they believe should not be sacrificed to the individualism of the capitalist market-place. These are core elements of what I have argued is a coherent political doctrine endorsed tacitly or otherwise by millions of people on this planet. They may, of course, be mistaken, but they are not obviously mistaken.

Nationalism should not be equated with fascism or racism, as Gellner recognises, although it may become infected by the latter notions. Nationalism, as a doctrine, from Herder onwards recognises the equality of nations. In both its romantic and instrumental-developmental versions it celebrates the diversity of national differences, and, therefore, in principle, it is not genocidal or racist. Racism after all presupposes a natural caste hierarchy of races. Nationalism amongst the peoples who were not in charge of the great powers was a reaction against empires which denied the equality of subject peoples. Nationalism as a political doctrine embraces the self-determination of all peoples, and therefore is historically and presently associated with democratisation and the generous extension of citizenship rights. People who take this line of argument think that racism and religious creeds have been more responsible for genocide than nationalism. Racism, by contrast with nationalism, ranks races in an evolutionary and moral hierarchy, and is therefore dispositionally genocidal; while religious believers, dogmatically convinced of their possession of the truth, may well be disposed to engage in mass-killings of non-believers. 
There are those who argue that the rise of nationalism is responsible for genocides in the modern world. They define nationalism as the ethnocentric glorification of the in-group, as the religious deification of the nation, or in Conor Cruise O'Brien's characteristically inflammatory words as 'the most effective engine for the mobilisation of hatred and destruction that the world has ever known'. ${ }^{8}$ They hold nationalism ultimately responsible for phenomena like the Holocaust. This view certainly became the conventional wisdom amongst western liberals in the aftermath of World War II, and indeed this idea was often used as an argument for resisting all manner of nationalist demands. The 'argument' is that from the ideal of the nation-state it is but a short-step to putting people into cattle-trucks to exterminate them. The implication is that nationalism cannot tolerate ethnic, racial or religious differences but must eliminate them. Such arguments are refuted, at least to my mind, by the existence of multi-ethnic, multi-racial and multi-religious nations, and by the fact of peaceful international relations between liberal democratic nations. However, because Gellner treats nationalism as the doctrine of 'one culture, one state' he does leave nationalism open to the charge that its central doctrine spells a simple choice between assimilation on the one hand, and genocide and forced expulsion or emigration on the other hand. It is here, once more, that the deficiencies are apparent in his grasp of the range of political forms open to modern political systems.

I have suggested enough to provide an initially plausible defence of the coherence and possible liberalism of nationalist doctrine. Let me go one step further to suggest what Gellner surprisingly does not: in practice all self-professedly modern ideologies, whether they be liberal, socialist or conservative are parasitic upon nationalist assumptions. Practical liberalisms, conservativisms and socialisms may be internationalist but that is not the same thing as saying they are genuinely cosmopolitan. Internationalism is parasitic upon nationalism and it is a category-mistake to elide it with cosmopolitanism.

\section{Conclusion.}

I have accepted, with qualifications, Gellner's arguments about the elective affinity between nationalism and modernity - and incidentally because I do not believe in 'post-modernity' which is a label for those who, as they say themselves, have lost their faith in reason. Like Gellner I have agreed that nationalism or nations have not been permanent features of human history - and, in

principle, we may choose to believe that the supersession of nationalism is not ruled out by historical evidence. Like Gellner, I have not denied that nationalism is a doctrine used to legitimate elites and counter-elites, that it is an ideology of mobilisation especially favoured by the disaffected intelligentsia - although I would deny that it is specially embraced by 'the lesser-examination passing classes' in Hobsbawm's cutting and inaccurate phrase ${ }^{89}$. Nor have I denied that nationalist 
arguments may be manipulated for illiberal purposes. Whether articulated by anti-colonial movements or by established political élites in control of a state machinery, nationalism may be used to obtain and exploit territorial, administrative, and economic monopolies. And like Gellner I accept that unless nationalist doctrine made some kind of rough sense of the modern world it could not be tapped by manipulative élites: why else is nationalist manipulation more successful than many other kinds of manipulation?

Where I differ from Gellner is first of all in his explicitly functionalist argumentation and in the primacy he gives to industrialisation in explaining the genesis and maintenance of nationalism. Other mechanisms have been conducive to the genesis and maintenance of nationalism - including explicitly political mechanisms. I have argued that on the logic of his own arguments his theory has greater retrodictive or predictive power than he suggests, and I have suggested, but not proved, that successful nation-building may depend much more on innovation rather than invention. I have suggested that Gellner's typology is deficient in its range, and that he cannot, as he suggests, maintain that some real-world types of nationalism fit his typology. These defects stem from the apolitical character of his theory, which is unaware of the range of stable political regimes in the modern world; relies on a culturally and materially reductionist account of political motivation ${ }^{90}$; neglects the autonomous role of politics in explaining the genesis of nationalism; misses the interdependencies between nationalism and democratisation; and, finally, fails to treat nationalism seriously as a political doctrine which, when suitably furbished is consistent with most of the liberal values Gellner holds dear. Nationalism is the major form in which democratic consciousness expresses itself in the modern world. It is to Ernest Gellner's credit that his thought helps us understand why that is so, and why it must be so. 
Endnotes.

1 The first draft of this chapter was presented to the Seminar on International Political Theory held at LSE in December 1993. A second draft was presented to the Political Economy Seminar at the University of Western Ontario in March 1994. I am grateful to the participants for disagreeing with me.

$2 \quad$ I vividly recall being a guest at the inaugural dinner of Professor Gordon Smith, held at the LSE in the Spring of 1989. I was an interloper-amongst specialists on German and EC politics, and was laughed at for maintaining that German unification would quickly occur after any collapse in the authority of the Communist Party in the German 'Democratic' Republic. All the assembled Germanists, Europeanists, Britons and Germans, bar one - Professor Smith who retained a judicious silence - assumed that the GDR was stable, and that West Germany was not interested in re-unification. The dinner-table consensus was that only 'a nineteenth-century Irish nationalist' could think the absurd thought that German unification was imminent. The assembled self-styled cosmopolitans decoded my thoughts as an irrational projection of what they assumed to be my ethnic sentiments about another divided nation - although the Germans present may have felt obliged to prove that they were 'good Germans' i.e. liberal, cosmopolitan, European and nonirredentist Germans. (Incidentally, I was wrong in a different way about the GDR - I assumed, wrongly that its communist elite would fight).

3 See Emest Gellner Thought and Change (London: Weidenfeld and Nicolson, 1964), $147-$ 78, 'Scale and Nation' Philosophy of the Social Sciences (1973), 3,*-**, 'Nationalism, or the new confessions of a justified Edinburgh sinner' in Spectacles and Predicaments (Cambridge: Cambridge University Press, 1979), 265-76, Nations and Nationalism (Oxford: Basil Blackwell, 1983), 'Nationalism and the two forms of cohesion in complex societies' in Culture Identity and Politics (Cambridge: Cambridge University Press, 1987), 6-28, 'Nationalism and politics in Eastern Europe', New Left Review (1991), 189: *_**, 'Nationalism reconsidered and E.H. Carr' Review of International Studies, (1992), 18: *_**.

4 A famous nineteenth century illustration of a liberal criticism of nationalism is Lord Acton's 1862 essay on 'Nationality' (reprinted in Essays in the History of Liberty: Selected Writings of Lord Acton (ed.) J.R. Fears (Indianapolis: Liberty Classics, 1985), 409-33. A recent illustration of socialist criticism of nationalism can be found in Eric Hobsbawm's Nations and Nationalism Since 1780 (Cambridge: Cambridge University Press, 1990).

5 The contemporary version of 'Dark Gods' theory takes a rationalist form in the writings of socio-biologists. See inter alia Pierre van den Berghe The Ethnic Phenomenon (****: ****, 1981)

6 Gellner, Thought and Change, 149. See also Nations and Nationalism, 130.

7 Ibid., 151.

8 Ibid., 152.

9 Ibid., 153. Gellner is citing the famous conclusion to Elie Kedourie's Nationalism (London: Hutchinson, 1960), 140. Kedourie thought that his question was the only criterion of political legitimacy capable of public and universal defence. Gellner's reply is that Kedourie's concept of good government may make sense in pre-modern times but not in modern society. He returns to the same disagreement in a more mocking tone in Nations and Nationalism: 'The question which Professor Kedourie asks with such eloquence is indeed one which a typical burgher in an agrarian society would ask himself, if one morning he just heard that the local Pasha had been overthrown and replaced by an altogether new one. If, at that point, his wife dared ask of the burgher what language the new Pasha spoke in the intimacy of his home life - was it Arabic, Turkish, Persian, French or English? - the hapless burgher would give her a sharp look, and wonder how he would cope with all the new difficulties when, at the same time, his wife had gone quite mad'. Kedourie's question is no longer coherent in a world in which accountable, participatory and representative government is possible, and in which a modern economy requires a national system of communications - Ibid., 127-8.

10 Gellner, Thought and Change, 155.

11 Ibid., 155, 157. 
Ibid., 159. Gellner adds in a footnote that 'It is of course possible for nominally independent political units to exist in a kind of educationally parasitic way. But the present argument is not really undermined by the existence of Monaco or Andorra', Ibid, 159, n.1.

13 Ibid, 160

14 Ibid.

15 Ibid., 166.

16 Ibid, 171.

17 Ibid, 168.

18 Ibid., 173.

19 Ibid.

20 Ibid., 174.

21 Ibid. Some now claim that highly educated French, Swiss-Deutsch and Italian speakers frequently speak to each other in English as a neutral second language.

22 Ibid., 177.

23 Perhaps that explains why when Gellner re-expressed the argument in Nations and Nationalism nearly two decades later there were some complaints that he had ignored the writings of North American scholars of the subject - see, for example, Boyd Shafer's 'Review of Emest Gellner's Nations and Nationalism', Canadian Review of Studies in Nationalism, XI (1): 141-2. Moreover, many surveyors of writings on nationalism, and many students, appear to see little difference between Gellner's arguments and those of Karl Deutsch's Nationalism and Social Communications (Cambridge: MIT Press, 1966, 2nd edition). However, there is this major difference: whereas Deutsch conveys the notion that the idea of nationalism is transmitted by newspapers, books, radios (and now televisions) to previously non-nationalist peoples, Gellner insists that it is the media themselves, 'the pervasiveness and importance of abstract, centralised, standardised, one to many communication, which automatically engenders the core idea of nationalism, quite irrespective of what in particular is being put into the specific messages transmitted ... That core message is that the language and style of the transmissions is important, that only he who can understand them, or can acquire such comprehension, is included in a moral and political community, and that he who does not and cannot, is excluded' - Nations and Nationalism, 127.

24 See for example Brian Barry, "Review of Ernest Gellner's Nations and Nationalism." Ethics (1984), (October): 182, Bernard, Crick, "The gad-fly and the eagle." New Statesman (1983/84): *, John Dunn, "For the good of the country." Times Higher Educational Supplement (1984):**, James Kellas "Review of Nations and Nationalism." International Affairs (1984), (January): **, Alan Ryan 'More country matters'. Sunday Times, (1984), ***, and Anthony Smith "Book Review: Ernest Gellner, Nations and Nationalism." Millennium, (1983), 280-82.

25 Nations and Nationalism, 129. One possible implication of Kedourie's arguments was that nationalism could be partially cleansed from the planet, presumably by the kind of education students used to undergo when they took Kedourie's courses on the History of Political Thought at the LSE. Pierre Trudeau, one of Kedourie's students, acted on Kedourie's premises, refusing to make significant concessions to Quebec nationalism, and thereby helped destabilise the Canadian federation.

Gellner does contest Kedourie's history of ideas, as well as his idealist insistence on the power of (bad) ideas, by defending Kant from Kedourie's indictment. He maintains that there is no relationship, other than a verbal one, between individual 'self-determination' and national 'selfdetermination, and that Kant was 'a very model for that allegedly bloodless, cosmopolitan, emaciated ethic of the Enlightenment' which romantic nationalists detested. All that nationalists and Kant have in common is that neither are, in Kedourie's sense, respecters of tradition - Nations and Nationalism, 133.

26 Nations and Nationalism, 129-30.

27 Ibid., 57.

28 Unlike Benedict Anderson who insists on the pivotal importance of 'print capitalism' in the genesis of nationalism (Imagined Communities: Reflections on the Origins and Spread of 
Nationalism (London: Verso, 1983) Gellner simply stresses the importance of print per se. Given that the large-scale production of bibles - which was so important in the development of European vernacular languages at the expense of Latin - was a state or state-church sponsored and approved project, it is not obvious why we should regard capitalism rather than the mass-production of texts as the salient cause in the creation of national languages. After all the nationalisms of what was Soviet Central Asia are built on national languages constructed by a state socialist regime rather than by 'print capitalism'.

29 This philosophy of history is stated at length in Ernest Gellner Plough, Sword and Book: The Structure of Human History (London: Collins-Harvill, 1988), which was published coterminously with the end of Gellner's long engagement with the best of Soviet Marxist scholarship - see Ernest Gellner State and Society in Soviet Thought (Oxford: Basil Blackwell, 1988).

30 Gellner, Thought and Change, 164-71.

31 Pre-modern examples might include Iceland, Korea and Japan.

32 Gellner, Nations and Nationalism, 95. This argument is very odd: as it excludes a not untypical form of nationalism - a reformist modernising nationalism 'from above', imposed by a Jacobin intelligentsia on a less than modern society.

33 Gellner oddly treats this case as a 'non-nationalist one' even though it is plainly what historians would call 'a satisfied nationalism' - Nations and Nationalism, 97. This suggests that in his thinking the typology is directed towards explaining nationalist conflicts, rather than forms of nationalism.

$34 \quad$ Gellner, Nations and Nationalism, 98.

35 The contrast between ethnic nationalism and western liberal nationalism is Gellner's theoretical and universalist re-working of John Plamenatz's contrast between Eastern and Western (European) nationalisms, which, in turn, is not dissimilar to Hans Kohn's contrast between civic and ethnic nationalisms - see John Plamenatz, 'Two types of nationalism', in Eugene Kamenka (ed.) Nationalism: The Nature and Evolution of an Idea (London: Edward Amold, 1973), Hans Kohn *****. Gellner argues that the key advantage of his approach is that the contrast between 'western' and 'eastern' nationalism emerges logically from the three dimensions of his typology Nations and Nationalism, 101.

36 Gellner, Nations and Nationalism, 101-9.

37 Ibid., 96.

38 Ibid., 63-87.

39 Ibid, 64.

40 Ibid., 65.

41 Ibid., 47.

42 Ibid., $43-50$

43 See for example Brendan O'Leary The Asiatic Mode of Production: Oriental Despotism, Historical Materialism and Indian History (Oxford: Basil Blackwell, 1989), Chs. 4-5.

44 Perry Anderson 'Science, Politics, Enchantment' in John Hall and Ian Jarvie (eds.) Transition to Modernity: Essays on Power, Wealth and Belief (Cambridge: Cambridge University Press, 1992), 207.

45 Gellner, Nations and Nationalism, 140.

46 I use the expressions 'modern society' and 'modernisation' throughout, in anticipation of the difficulties attached to Gellner's arguments about the relationships between nationalism and industrialisation.

47 I have used Jon Elster's formalisation of logically impeccable functionalist argumentation see Ulysses and the Sirens (Cambridge: Cambridge University Press, 1979), 28-35, and Explaining Technical Change (Cambridge: Cambridge University Press, 1983).

48 Elster, Ulysses and the Sirens, 30.

49 The same logic explains why nationalists were often liberal feminists, promoting the education of boys and girls, and men and women, outside the home in national educational systems. 
50 Jean-Jacques Rousseau The Government of Poland, translated by Wilmoore Kendall, (Indianapolis, Hackett, 1985), Chapter xii, and Chapter iv.

51 This is the principal burden of Michael Mann's criticism of Gellner - 'The emergence of modern European nationalism', in Transition to Modernity: Essays on Power, Wealth and Belief (Cambridge: Cambridge University Press, 1992), 137-163

52 See inter alia Hugh Seton Watson's Nations and States: An Inquiry into the Origins of Nations and the Politics of Nationalism (London: Methuen, 1977), 15-88, which treats the British, Irish, French, Iberian, Dutch, Scandinavian, Swiss and Russian nations as 'old and continuous'.

53 John Armstrong Nations before Nationalism (Chapel Hill: University of North Carolina Press, 1982), Anthony D. Smith The Ethnic Origins of Nations (Oxford: Basil Blackwell, 1986).

54 Anthony Smith, 'Book Review: Ernest Gellner, Nations and Nationalism.' Millennium (1983), 280-82.

55 Liah Greenfeld Nationalism: Five Roads to Modernity (Cambridge, Mass: Harvard University Press, 1992).

56 Connor observes that the 'vast disagreement among eminent authorities' on the modernity of nationalism "has been made possible by the near absence of conclusive evidence. Nationalism is a mass phenomenon. The fact that members of the ruling elite or intelligentsia manifest national sentiment is not sufficient to establish that national consciousness has permeated the value-system of the masses. And the masses, until recent times totally or semi-illiterate, furnished few hints concerning their view of group-self' - Walker Connor, 'When Is a Nation ?', in his Ethnonationalism: the quest for understanding (Princeton: Princeton University Press, 1994), 212. 57 Smith, The Ethnic Origins of Nations, 18.

58 Greenfeld, Nationalism, 1. My criticism of the conceptual confusions in this work is not a criticism of the empirical originality and range of Greenfeld's researches. However, they are best understood, contrary to what she thinks, simply as studies in early forms of 'national consciousness' in five countries.

59 Connor has been a stern critic of 'terminological chaos' in this field - see inter alia his article 'A Nation is a Nation, is a State, is an Ethnic Group, is a ...' Ethnic and Racial Studies, 1 (1978), 377-400, reprinted in Ethnonationalism, 90-113. However, his astringent criticisms of others is somewhat by adding the term 'ethnonationalism' to the available chaos.

60 Anthony Smith recognises that nationalism has the kind of range which Greenfeld suggests, but narrows his conception of nationalism proper to 'an ideological movement for attaining and maintaining autonomy, unity and identity on behalf of a population deemed by some of its members to constitute an actual or potential "nation", National Identity, (Harmondsworth: Penguin, 1991), 72 ff.

61

62

Gellner, Nations and Nationalism, 74-75.

Ibid., 110-122.

63 The most feasible form in which widespread secessionism will occur across Europe will take the form of departures from the European Union if it becomes a federation. Given that The EU has for the time being been deprived of its geo-political rationale, and now has to rely purely upon instrumentalist/materialist bases for co-operation, it may become subject to all the predictable strains that nationalism brings to federal systems.

64 My discussion has been only casually empirical. If I was to answer properly the question " has there been a nationalist revival in the liberal advanced industrialised OECD ?' I would need to provide hard data on indicators like the following: (a) support for nationalist parties, (b) the formation and impact of new nationalist parties, (c) evidence of re-learning of old languages and cultural traditions, (d) public opinion poll-data showing rising nationalist secessionist or unificationist sentiment, \& (e) increases in irredentist/ jingoistic political thetoric amongst politicians and intelligentsias.

65 The latter claim is one I have advanced with several colleagues - see Brendan O'Leary and John McGarry, The Politics of Antagonism: Understanding Northern Ireland (London, Atlantic Heights, N.J.: Athlone, 1993), ch. 8 and also Brendan O'Leary, Tom Lyne, Jim Marshall and Bob 
Rowthom, Northern Ireland: Sharing Authority (London: Institute for Public Policy Research, 1993).

66 For example James Mayall's otherwise excellent Nationalism and International Society (Cambridge: Cambridge University Press, 1990), esp. p. 64, suggested that legal and political opinion within the state-system, and the geo-political interests of the two super-powers, had combined to place an effective moratorium on the prospects of further secessions. One of Mayall's mistakes was to suggest that 'there are no more empires to collapse', ibid.

They expected bureaucratisation and rationalisation to erode cultural heterogeneity. To caricature this view: we would all become mono-cultured, though our mono-culture would be the rationalisation of all cultures. In efficient states we would all eat Italian food, listen to Sony Walkmans, distribute welfare like the Swedes and make love like the French, and in inefficient states we would eat American food, listen to Swedish pop music, distribute welfare like the Italians, and make love like the English.

68 Nations and Nationalism, 100.

69 In any case I have difficulties with the alleged 'western liberal nationalisms'. These are supposed to have been the civic-territorial forms of nationalism - by contrast with the ethniccommunitarian types. Britain, France and the USA are meant to be the exemplars of western liberal nationalism. The Catholics of the British Isles, the provincials and Jews of France, the Red Indians and the black slaves of the USA do not have histories which fit easily with this 'type'. As Bill Kissane has suggested it seems best to say that civic nationalism is the name often given to a nationalist people who already have a state or territorial unit of government; whereas ethnic nationalism is the name often given to a people who do not have a state, or territorial unit of government.

10 Peter Alter's typology usefully differentiates 'risorgimento nationalism', 'reform nationalism' and 'integral nationalism' - Nationalism (London: Amold, 1985), Wolfgang Mommsen distinguishes liberal, imperialist, fascist and contemporary nationalisms ('The varieties of the nation-state in modern history: liberal, imperialist, fascist and contemporary notions of nation and nationality' in Michael Mann (ed.) The Rise and Decline of the Nation-State (Oxford: Basil Blackwell, 1990), while John Hall distinguishes nationalisms 'from above', nationalisms based on 'desire and fear blessed by opportunity' (Latin America), risorgimento nationalism, and integral nationalism - 'Nationalisms: Classified and Explained'. Daedalus, 122, (1993), 3: 1-28.

71 Gellner, Nations and Nationalism, 55. This statement sits oddly with a clear disclaimer: 'It is not claimed that, even in the modern world, nationalism is the only force operating, or an irresistible one', 138.

72 John McGarry and Brendan O'Leary, 'Introduction: The Macro-Political Regulation of Ethric Conflict' in John McGarry, and Brendan O'Leary (eds.) The Politics of Ethnic Conflict Regulation: Case Studies of Protracted Ethnic Conflicts (London: Routledge, 1993), pp. 1-47.

73 Ibid. Federation includes all types of genuine territorial autonomy. Mixed types are also possible: for example, a democratic condominium in a bi-cultural region could combine principles of arbitration, federation and consociation.

74 See the sober case studies in William J. Durch (ed.) The Evolution of UN Peacekeeping : Case Studies and Comparative Analysis (New York: St Martin's Press, 1993).

75 Gellner, Nations and Nationalism, 138.

76 T. Vanhanen, The Process of Democratisation: A Comparative Study of 147 States (*****: Crane Russack, 1990),

77 Ibid., 124-5. Compare the very similar verdict reached by Benedict Anderson in the same year: 'unlike other isms, nationalism has never produced its own grand thinkers: no Hobbeses, Tocquevilles, Marxes or Webers', and therefore it should not be compared with political doctrines, but rather with kinship and religion - Imagined Communities, 14-15. It is odd that a New Left author fails to classify Weber as a nationalist grand thinker, and odder still that Rousseau, Burke, J.S. Mill and Friedrich List are not seen as nationalist grand thinkers.

78 Gellner's contempt is far more provocative than the angst and cliche ridden English liberalism which opines that nationalism is the 'starkest political shame of the twentieth century, the 
deepest, most intractable and yet most unanticipated blot on the political history of the world since the year 1900' - John Dunn Western Political Theory in the Face of the Future (Cambridge: Cambridge University Press, 1979), ****.

79 In the cases of all these authors such readings are misleading. Burke can be read, like Rousseau as an exponent of the thesis that nations have the right to resist rulers who do not meet the obligations expected of them by organically developed nations, and List consistently advocated a system of national economy for the USA and France, as well as his native Germany - see Roman Szporluk, Communism and Nationalism: Karl Marx versus Friedrich List (New York: Oxford University Press, 1991), 96-114.

80 Brian Barry, 'Nationalism' in David Miller, Janet Coleman, William Connolly and Alan Ryan (eds.) The Basil Blackwell Encyclopaedia of Political Thought (Oxford: Basil Blackwell, 1987), 352-4.

81 For a conservative's perplexed glance at national self-determination see Kedourie's Nationalism, 62-91.

82 Daniel Patrick Moynihan, a man whose very name suggests he should know better, eloquently expresses this anxiety well when he call his recent diatribe against national selfdetermination Pandemonium: Ethnicity in International Politics (Oxford: Oxford University Press, 1993).

83 In practice many such lawyers are the paid apologists of states which are either satisfied nation-states or states afraid of the implications of liberal nationalism.

84 This argument is expressed well by Harry Beran in his article 'A Liberal Theory of Secession' Political Studies *** (1984)****

85 See footnote 65.

86 Barry, 'Nationalism', 352-4.

87 Barry provides an astringent review of the arguments of cosmopolitan liberals who believe in the unrestrained movement of people and money - see his 'The quest for consistency: a sceptical view' in Brian Barry and Robert E. Goodin (eds.) Free Movement: Ethical Issues in the Transnational Migration of People and of Money (University Park Pennsylvania: The Pennsylvania State University Press, 1992), 279-88.

88 Conor Cruise O'Brien 'A Lost Chance to Save the Jews ?' New York Review of Books $(1989,30: 7: 27-8,35)$. Gellner has written an incisive criticism of O'Brien's views on nationalism and religion - see 'The Sacred and the National' LSE Quarterly, 3, 4 (1989), 357-69.

89 Nations and Nationalism since 1780,*.

90 Can Gellner explain why people are willing to die for their nations ? 'It is hard to imagine anyone dying with much conviction on behalf of a precondition for access to the more remunerative sections of a labour market' (John Dunn ***** 1984). 